\title{
Kinetics of Net RNA Degradation during Development in Dictyostelium discoideum
}

\author{
By THE LATE JOSEPH WALSH AND BARBARA E. WRIGHT \\ Boston Biomedical Research Institute, Department of Developmental Biology, \\ 20 Staniford Street, Boston, Massachusetts 02114, U.S.A.
}

(Received 21 February 1978)

\begin{abstract}
Based on dry weight, first-order kinetics adequately describe the net decrease of RNA in Dictyostelium discoideum NC-4 until culmination, when a cessation of RNA degradation occurs. Between aggregation and sorocarp formation, the cells lose $40 \%$ of their RNA, or $19 \mathrm{~mm}$-glucose equivalents expressed in terms of cell volume at aggregation. In sorocarps the spores contain a disproportionately large amount of RNA. Net RNA contents in sorocarps and in spores are unaffected by the availability of exogenous glucose. The relationship of dry weight, cell number and packed cell volume during differentiation is given.
\end{abstract}

\section{INTRODUCTION}

Dictyostelium discoideum NC-4 provides a simple model of eukaryotic differentiation and development. Changes in cellular metabolites, enzymes and products follow a predictable pattern. One major constituent of the cells, RNA, has been found to decline dramatically (White \& Sussman, 1961), although great variation was observed between two experiments: in one, RNA decreased from about 1000 to $150 \mu \mathrm{g}\left(10^{8} \text { cells }\right)^{-1}$, and in the other, from 800 to $330 \mu \mathrm{g}\left(10^{8} \text { cells }\right)^{-1}$. Since these qualitative data were reported, a quantitative kinetic model of carbohydrate metabolism in wild-type $D$. discoideum NC-4 has been developed (Wright, 1973; Wright \& Park, 1975; Wright et al., 1977). Quantitative data have also been obtained which relate, in the same cell population, the levels of total carbohydrate and of specific saccharides during differentiation (Rosness \& Wright, 1974). These analyses indicated that the pentose of RNA must serve as a source of glucose equivalents for end-product saccharide synthesis. It therefore became essential to obtain statistically significant data regarding the amount of RNA used between aggregation and sorocarp formation, for inclusion in the kinetic model: such data are reported here. The levels of RNA in the two major cell types of $D$. discoideum were also determined, as kinetic models for each type are under construction. In addition to these new quantitative data, this study provides the most accurate information available regarding dry weight-cell volume-cell number relationships during differentiation, allowing investigators to convert data expressed in various ways.

\section{METHODS}

Materials. Yeast RNA (60 to $80 \%$ native RNA) was obtained from Worthington Biochemicals; orcinol monohydrate from Baker Chemical Co. (Phillipsburg, N.J., U.S.A.); and the Bacto-yeast extract, Bactopeptone and agar (technical grade) for media were from Difco. Other reagents and supplies were from normal commercial sources.

Growth of cells. Amoebae of Dictyostelium discoideum NC-4 (ATCC 24697) were grown in association with $E$. coli on nutrient agar in a humidified incubator at $22.0 \pm 0.5{ }^{\circ} \mathrm{C}$, relative humidity 75 to $80 \%$. After most of the bacterial lawn had cleared, but before amoebae began aggregating, the cells were rinsed off with cold 
distilled water and separated from the remaining bacteria by differential centrifugation (Liddel \& Wright, 1961). The final pellet was resuspended in cold distilled water and spread at a density of about $4 \times 10^{6}$ cells $\mathrm{cm}^{-2}$ on sheets of non-nutrient agar (area about $1000 \mathrm{~cm}^{2}$ ) from which all condensed water had been carefully removed with absorbent paper. Cells were returned to the humidified incubator for development. This careful control over the environmental moisture and temperature led to synchronous develcpment.

Harvesting of cells. Cells were harvested from non-nutrient agar with cold distilled water, centrifuged and resuspended in a graduated cylinder. Samples of 1.0 or $2.0 \mathrm{ml}$ were pipetted (i) into tared weighing dishes and oven-dried to constant weight, (ii) into Shevsky-Stafford centrifuge tubes and centrifuged at $1000 \mathrm{~g}$ for $15 \mathrm{~min}$ to determine packed cell volume and (iii) into polyethylene vials which were then frozen in liquid nitrogen for later RNA determinations. 'Zero-hour' cells were from the amoebal suspension being spread on to non-nutrient agar; a portion of this suspension was also diluted 100-fold and cells were counted in a haemocytometer. Counts of cells harvested at early stages of aggregation approximated to those obtained for amoebae.

$R N A$ determination. The RNA content of two frozen samples from each cell suspension was determined in separate runs using the orcinol reaction. Frozen cell samples were thawed in the presence of $5.0 \mathrm{ml}$ cold $10 \%(\mathrm{w} / \mathrm{v})$ trichloroacetic acid (TCA), washed twice with $10 \% \mathrm{TCA}$, twice with $95 \%(\mathrm{v} / \mathrm{v})$ ethanol and hydrolysed in $4.0 \mathrm{ml} 1 \mathrm{M}-\mathrm{KOH}$ overnight at $37{ }^{\circ} \mathrm{C}$. Then $0.8 \mathrm{ml} 6 \mathrm{M}-\mathrm{HCl}$ and $4.0 \mathrm{ml} 5 \% \mathrm{TCA}$ were added to precipitate substances not hydrolysed by treatment with base, leaving the ribonucleotides in solution (Schneider, 1957). Treatment for $3 \mathrm{~d}$ with base did not increase the amount of orcinol-reacting material. The recovery of yeast RNA dissolved in distilled water and added to frozen cell samples thawing in $10 \%$ TCA was $95 \%$.

The supernatant was analysed according to Mejbaum (1939). For each run of the assay. yeast RNA was hydrolysed in base together with the samples and used as the standard.

To detect the possible degradation of RNA during sample harvesting, two identical samples of cells were harvested from non-nutrient agar and then handled sequentially so that the portions of the second sample were frozen after double the time needed for processing the first sample had elapsed. They were found to contain identical amounts of RNA.

Spore preparation. In several experiments, separate from those above, a pure spore suspension (as determined by microscopic examination) was prepared from sorocarps. After taking samples for dry weight and RNA determinations, the suspension of whole sorocarps was vigorously shaken and vortexed. The suspension was diluted with either distilled water or buffer $\left(10 \mathrm{~mm}-\mathrm{Na}_{2}\right.$ EDTA/10 mM-potassium phosphate buffer, $\mathrm{pH} 6 \cdot 5$ ), filtered through four layers of washed cheesecloth and briefly centrifuged at $2000 \mathrm{~g}$. A second filtration and centrifugation was needed to remove all stalk material, after which the spores were resuspended in a small amount of distilled water. Samples were taken for dry weight determination and frozen for later RNA analysis.

RNA as total carbohydrate. An amount of yeast RNA equivalent to the amount in $25 \mathrm{mg}$ lyophilized amoebae was extracted using the method of Rosness \& Wright (1974). It was reacted together vith glucose standards in the phenol-sulphuric acid carbohydrate assay of Dubois et al. (1956), and absorbance was read at $490 \mathrm{~nm}$; based on weight, glucose gives $72 \%$ of the absorbance of pentose in this assay.

\section{RESULTS}

\section{Cell number-packed cell volume-dry weight relationships}

Figure 1 shows the change in dry weight during development, expressed as $\mathrm{mg}\left(10^{8}\right.$ initial cells $)^{-1}$. Figure 2 shows the change in packed cell volume, expressed as $\mathrm{ml}\left(10^{8}\right.$ initial cells $)^{-1}$. Vertical bars indicate the mean \pm standard error for each time-point. Of the three determinations, dry weights showed the least variation between duplicate samples; this variation was generally less than $3 \%$ even for sorocarp samples. Packed cell volumes were observed in centrifuge tubes and were not corrected for extracellular water (Barravecchio et al., 1969); these determinations showed the greatest variation between duplicate samples.

\section{Kinetics of the decrease in RNA content}

Figure 3 shows the change in RNA content, expressed as log [mg RNA (mg dry wt) ${ }^{-1}$ ], during the course of development. Each point is the mean value for at least four experiments. The apparent rate constant $(k)$ for $\mathrm{mg}$ RNA ( $\mathrm{mg}$ dry wt $)^{-1}$ from 0 to $20 \mathrm{~h}$, as calculated from the slope of the least-mean-squares line, is $0.022 \mathrm{~h}^{-1}\left(r^{2}=0.97\right)$. Since the fit of the data is good, first-order kinetics adequately describe RNA degradation from the beginning of 


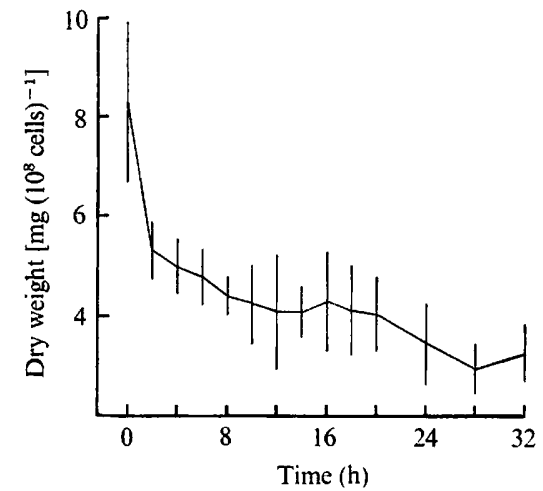

Fig. 1

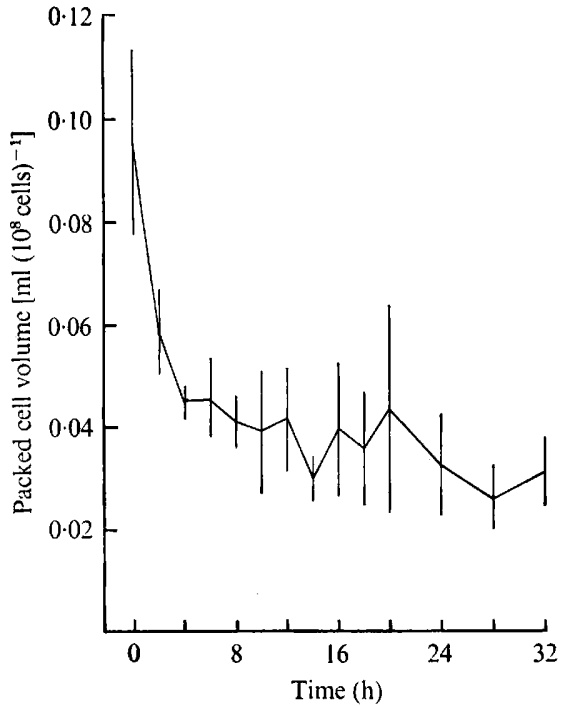

Fig. 2

Fig. 1. The relationship of dry weight to initial cell number during differentiation of $D$. discoideum. Fig. 2. The relationship of packed cell volume to initial cell number during differentiation of D. discoideum.

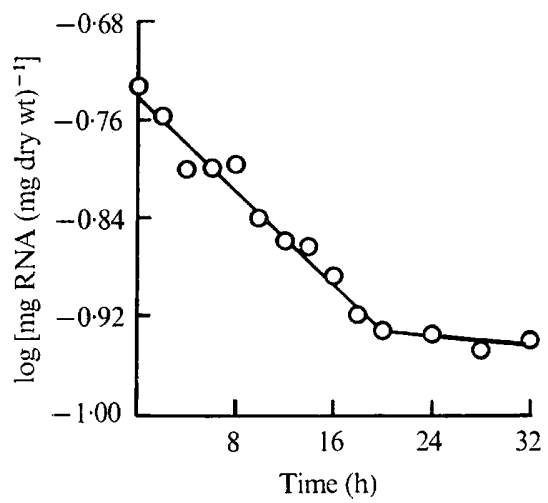

Fig. 3. The decrease in RNA content during differentiation of $D$. discoideum, expressed as $\log$ [mg RNA (mg dry wt) ${ }^{-1}$.

starvation to the end of culmination; the rate of RNA degradation then changes abruptly and is insignificant between culmination and sorocarp maturation.

The hypothesis that the variability in the data was due to initial differences in RNA content, rather than analytical error, random variation of samples etc., was tested. If RNA degradation follows first-order kinetics such that the amount of RNA present at time $t\left(\mathrm{RNA}_{t}\right)$ equals $\mathrm{RNA}_{0} \times \mathrm{e}^{-k t}$, another initial quantity $\left(\mathrm{RNA}^{\prime}{ }_{0}\right.$ ) differs from the first by the factor $\left(\mathrm{RNA}_{0}{ }_{0} / \mathrm{RNA}_{t}\right)$. Thus every $\mathrm{RNA}_{t}^{\prime}$ can be normalized to the $\left(\mathrm{RNA}_{0} / \mathrm{RNA}_{0}\right) \times \mathrm{RNA}_{t}$ equivalent $\mathrm{RNA}_{t}$ by dividing by $\left(\mathrm{RNA}_{0}^{\prime} / \mathrm{RNA}_{0}\right)$. If the spread in the raw data is due to different initial RNA contents of the amoebae, and the RNA decrease follows first-order kinetics, normalization of the raw data would bring them closer to the ideal $\mathrm{RNA}_{t}$ values and decrease the variance.

The RNA value for each sample at different times after initiation of development was normalized as indicated above on the basis of RNA per dry weight, cell number, and packed cell volume; the ideal initial RNA content was taken as the mean value for 'zero-hour' cells. 


\section{Table 1. RNA content of sorocarps and their spores}

Cells '+ glucose' were plated from the same amoebal suspension on to non-nutrient agar made $25 \mathrm{~mm}$ in glucose. Spores account for $85 \%$ of the sorocarps' dry weight (C. L. Rutherford, unpublished data); thus the percentage of sorocarp RNA in spores was calculated as $[(0 \cdot 85 \times$ spore RNA)/(sorocarp RNA)] $\times 100$.

Expt 1: $28 \mathrm{~h}$
Sorocarps
Spores
Expt $2: 48 \mathrm{~h}$
Sorocarps
Spores
Sorocarps + glucose
Spores + glucose

$\begin{array}{cc}\begin{array}{c}\text { Mean RNA } \\ \text { content } \pm \text { S.E.M. }\end{array} & \begin{array}{c}\text { Sorocarp } \\ \text { RNA in } \\ \left.\text { [mg (mg dry wt) })^{-1}\right]\end{array} \\ \begin{array}{c}\text { spores }(\%) \\ 0 \cdot 125 \pm 0.003\end{array} & 91.8 \\ 0 \cdot 135 \pm 0.009 & \\ & \\ 0 \cdot 145 \pm 0.006 & 97.3 \\ 0 \cdot 166 \pm 0.010 & \\ 0 \cdot 145 \pm 0.004 & 93.8 \\ 0 \cdot 160 \pm 0.005 & \end{array}$

The means and standard errors for the normalized data were similar to those for the raw data, and the graphs were virtually identical. Testing the paired mean values of raw and normalized data (excluding zero-hour data) with Student's $t$-test showed that there was no significant difference at the $10 \%$ level of confidence. The F-test was applied to the ratios of the raw and normalized variances at each time-point. Only four were significantly different at the $5 \%$ level: these were the $12,18,24$ and $28 \mathrm{~h}$ concentrations of RNA based on packed cell volume. The F-test applied to the summed variances of raw and normalized data gave no significant differences $(P>0.05)$. Therefore variability in the experiments was not primarily due to different initial RNA contents of the amoebae.

\section{$R N A$ contents of sorocarps and their spores}

The RNA contents of whole sorocarps and their spores, expressed as mg RNA(mgdry wt) ${ }^{-1}$, are shown in Table 1. Data are from two typical experiments. It can be seen that (i) spore preparations were enriched in RNA compared with the sorocarps from which they were derived, (ii) the discrepancy became greater as the sorocarps matured and (iii) differentiation of cells on 'non-nutrient' agar made $25 \mathrm{~mm}$ in glucose did not affect the RNA content of mature sorocarps or their spores. If $85 \%$ of the dry weight of the sorocarp is composed of spores (C. L. Rutherford, unpublished data) then the spores contain $92 \%$ of the sorocarp's RNA at $28 \mathrm{~h}$, and $95 \%$ at $48 \mathrm{~h}$.

\section{$R N A$ in total carbohydrate}

RNA is a component of the total carbohydrate of a variety of cells as measured with the anthrone (Ashwell, 1957) or phenol-sulphuric acid reagents. Yeast RNA dissolved in the buffer-detergent fraction of Rosness \& Wright (1974) was repeatedly found to form as much colour with the phenol-sulphuric acid reagent as did one-quarter of its weight of glucose, in spite of the fact that nearly one-half of the weight of RNA consists of the sugar ribose. While RNA is $56 \mathrm{~mm}$ in ribose in cells at aggregation (see below), based upon its specific determination in the orcinol reaction, in terms of the phenol-sulphuric acid reaction it reacts as would $27 \mathrm{~mm}$-glucose. Therefore, RNA represents about one-quarter of the $100 \mathrm{~mm}$ total carbohydrate as glucose at aggregation (Rosness \& Wright, 1974).

\section{DISCUSSION}

The quantity of RNA found in developing cells and its constant rate of loss until formation of the fruiting body are consistent with previous data (White \& Sussman, 1961; Hames \& Ashworth, 1974). Synthesis of RNA, as measured by incorporation of radioactive uridine, also occurs throughout development (Pannbacker, 1966; Inselburg \& Sussman, 1967) and 
is due to a fraction that is rapidly turning over (Rutherford et al., 1974) and to replacement of at least $75 \%$ of the cells' ribosomes (Cocucci \& Sussman, 1970). Therefore, the net rate of RNA decrease is the difference between the rates of synthesis and degradation. The nucleotides resulting from net RNA degradation must subsequently be removed from their pool, which stays relatively constant in size during development (Pannbacker, 1966).

In the first $2 \mathrm{~h}$ after transfer to non-nutrient agar each cell loses $40 \%$ of its RNA; by aggregation (about $10 \mathrm{~h}$ ) $60 \%$ is lost. This cannot be accounted for by lysis, given the good recovery of viable cells. In addition to the breakdown of the $D$. discoideum RNA discussed above, major sources of RNA loss include the degradation of ingested bacteria as a carbon source, and the excretion of cellular material to the surrounding medium (Krichevsky \& Love, 1965). This excretion of RNA and protein has been found only during the first few hours after transfer of cells to fresh media (Hames \& Ashworth, 1974). The relative importance of these various processes has yet to be assessed.

One way to look at the loss of ribonucleotides is in terms of the glucose potentially coming from the conversion of their ribose moiety via the hexose monophosphate shunt (Wright \& Bloom, 1961). Working directly from the RNA concentrations (figure not shown) assuming an average ribonucleotide molecular weight of 350 and correcting for extracellular space (Barravecchio et al., 1969), the cells are $56.0 \mathrm{~mm}$ in RNA at aggregation, or, in terms of glucose derived from the ribose portion of ribonucleotides, $46.7 \mathrm{~mm}$-glucose equivalents. These cells will lose $40 \%$ of their RNA, i.e. $18.7 \mathrm{~mm}$-glucose equivalents of those at aggregation, by the time they become sorocarps. Concentrations of cellular constituents are best expressed in terms of cell volume at aggregation because of the inexactness of packed cell volume and extracellular space determinations at the later stages of differentiation. These RNA values agree with those previously calculated (Wright et al., 1977) based on the decrease from $0 \cdot 147 \mathrm{mg}$ RNA (mg dry wt) ${ }^{-1}$ at aggregation to $0.116 \mathrm{mg}$ RNA (mg dry wt) ${ }^{-1}$ at sorocarp (about $30 \mathrm{~h}$ ), the loss of $24 \%$ of the cells' dry weight during this period, and the relationship that $1 \mathrm{mg}$ dry weight is equivalent to $0.0076 \mathrm{ml}$ packed cell volume at aggregation. The values of $46 \mathrm{~mm}$-glucose equivalents at aggregation and $28 \mathrm{~mm}$-glucose equivalents at sorocarp were used in a computer model simulating the metabolism of $D$. discoideum during development. The decrease in RNA, together with the loss of a fraction of the cells' soluble glycogen, was an adequate source of glucose equivalents for the synthesis of the new saccharide end-products of differentiation (Wright et al., 1977).

Even in very young sorocarps the spores contain a disproportionate amount of RNA, which shows a difference in the relative rates of synthesis and degradation, as might be expected considering the fate of the two cell types, and reflects differentiation-correlated changes in the metabolism of pre-stalk and pre-spore cells. The lack of an effect of exogenous glucose on the RNA content of sorocarps or their spores extends the finding of Hames \& Ashworth (1974) that unusually high glycogen levels in cells do not influence the rate of RNA loss during development.

This investigation was supported by research grants AG00433 and AG00260 from the National Institutes of Health.

\section{REFERENCES}

ASHWELl, G. (1957). Colorimetric analysis of sugars. Methods in Enzymology 3, 73-105.

Barravecchio, J., Baumann, P. \& Wright, B. (1969). Cell volume determinations of Dictyostelium discoideum. Applied Microbiology 17, 641-642.

Cocucci, S. M. \& Sussman, M. (1970). RNA in cytoplasmic and nuclear fractions of cellular slime mold amoebas. Journal of Cell Biology 45, 399407.
Dubois, M., Gilles, K. A., Hamllton, J. K., Rebers, P. A. \& Smith, F. (1956). Colorimetric method for determination of sugars and related substances. Analytical Chemistry 28, 350-356.

Hames, B. D. \& Ashworth, J. M. (1974). The metabolism of macromolecules during the differentiation of myxamoebae of the cellular slime mould Dictyostelium discoideum containing different amounts of glycogen. Biochemical Journal 142, 301-315. 
INSELBURG, J. \& SUSSMAN, M. (1967). Incorporation of ${ }^{3} \mathrm{H}$-uridine into RNA during cellular slime mould development. Journal of General Microbiology 46, 59-64.

KRICHEVSKY, M. I. \& Love, L. L. (1965). Efflux of macromolecules from washed Dictyostelium discoideum. Journal of General Microbiology 41, 367-374.

LidDel, G. U. \& Wright, B. E. (1961). The effect of glucose on respiration of the differentiating slime mold. Developmental Biology 3, 265-276.

Mejbaum, W. (1939). Über die Bestimmung kleiner Pentosemengen, insbesondere in Derivaten der Adenylsäure. Hoppe-Seyler's Zeitschrift für physiologische Chemie 258, 117-120.

PANNBACKeR, R. G. (1966). RNA metabolism during differentiation in the cellular slime mold. Biochemical and Biophysical Research Communications 24, 340-345.

Rosness, P. A. \& Wright, B. E. (1974). In vivo changes of cellular trehalose and glycogen during differentiation of Dictyostelium discoideum. Archives of Biochemistry and Biophysics 164, 60-72.

Rutherford, C. L., Kong, W. Y., PARK, D. \& WRIGHT, B. E. (1974). Precursor-product relation- ships between nucleotides and RNA during differentiation in Dictyostelium discoideum. Journal of General Microbiology 84, 173-187.

SCHNEIDER, W. C. (1957). Determination of nucleic acids in tissues by pentose analysis. Methods in Enzymology 3, 680-684.

White, G. J. \& Sussman, M. (1961). Metabolism of major cell components during slime mold morphogenesis. Biochimica et biophysica acta 53, 285-293.

Wright, B. E. (1973). Critical Variables in Differentiation. Englewood Cliffs, New Jersey: Prentice Hall.

WRIGHT, B. E. \& BLOOM, B. (1961). In vivo evidence for metabolic shifts in the differentiating slime mould. Biochimica et biophysica acta 48, 342-346.

Wright, B. E. \& PARK, D. J. M. (1975). An analysis of the kinetic positions held by five enzymes of carbohydrate metabolism in Dictyostelium discoideum. Journal of Biological Chemistry 250, 2219-2226.

Wright, B. E., TAI, A. \& KILlick, K. A. (1977). Fourth expansion and glucose perturbation of the Dictyostelium kinetic model. European Journal of Biochemistry 74, 217-225. 